\title{
The Impact of Perceptions of Policy Dissemination, Communication, and Motivation on National Character Knowledge of Primary School Teachers
}

\author{
Husni Mubarok \\ Doctoral Student, \\ Universitas Negeri Jakarta, \\ Jakarta, Indonesia; \\ Faculty of Tarbiyah, \\ Institut Agama Islam Kudus, \\ Kudus, Indonesia

\section{Ma'ruf Akbar} \\ Faculty of Science Education, \\ Universitas Negeri Jakarta, \\ Jakarta, Indonesia

\section{Endry Boeriswati} \\ Faculty of Science Education, \\ Universitas Negeri Jakarta, \\ Jakarta, Indonesia
}

DOI: https://doi.org/10.36941/jesr-2021-0036

\section{Abstract}

This study measures perceptions of policy dissemination, communication, and teacher motivation on knowledge of primary school teachers' nationality character. The survey method with structural equation models was used involving 144 primary school teachers in Pati, Central Java, Indonesia. The instruments were in the form of questionnaires on national character knowledge, policy dissemination, communication, and teacher motivation. The concern in this study is the cognitive abilities of primary school teachers in the form of knowledge of national characters and non-cognitive abilities in the form of policy dissemination, communication, and motivation. The study results indicated an influence of policy dissemination, communication, and motivation on primary school teachers' national character knowledge. Primary school teacher motivation provided a significant positive value on the teacher's nationality character's experience. In addition to the influence of non-cognitive abilities on cognitive abilities, there was also a positive influence between the non-cognitive abilities of primary school teachers. This study recommends that policymakers, including school principals, have an excellent opportunity to succeed in national character education, including character education in general, if policy dissemination is implemented optimally and appropriately to primary school teachers as educators.

Keywords: Character building; Character Knowledge; Perceptions of Policy Dissemination; Communication; Motivation 


\section{Introduction}

\subsection{Background of the Study}

Character education is a discipline that develops with a deliberate attempt to optimize students' ethical behavior (Berkowitz \& Hoppe, 2009; Katilmiş et al., 2011). In various countries, character education has become a concept of developing moral awareness, which is very important for students (Lickona, 2007). The United States, for instance, implements character education as part of an educational curriculum that aims to improve student morale that started from the early days of the State (Howard et al., 2004). On the other hand, South Africa implements character education in the form of factors of religion, attitude, and culture in the school environment, aiming to shape student morale (Nyabul, 2009). Meanwhile, South Korea uses character education to strengthen aspects of the education system, such as self-control, sincerity, freedom, acceptance of responsibility, development of traditional culture, commitment to national development, respect for humanity, contribution to world peace. So, character education is a regular subject in South Korean schools to produce moral reform (Gou-Zeh, 1979).

Apart from the many countries implementing character education through educational curricula and reconstructing their curriculum systems, students' moral problems are still challenging to solve (Chowdhury, 2016). The study of character education has become an interest for global scientists in recent years (Yemini et al., 2019). This study's need is due to increased violence at school, absenteeism, dropout rates, and low student learning outcomes (Was et al., 2006).

In carrying out character education, a primary school teacher must have adequate knowledge of the character. Kamaruddin (2012) stated that character knowledge is about the teacher's cognitive understanding of ways to carry out students' character-based learning process. A teacher who carries out character education must also understand the related policies. Klassen et al. (2018) stated that this understanding shapes the teacher's perception of the government's policy dissemination. Meanwhile, in shaping student morale through character education, good communication from the teacher is needed. This communication is an essential means for teachers to deliver and implement a characterbased learning process (Abdorrakhman, 2008). In carrying out this character-based learning process, teacher motivation is an important factor. The goals of character education can be implemented according to character education goals (Rokhman et al., 2014). Thus, the perceptual aspects of policy dissemination, communication, and motivation on primary school teachers' character knowledge are critical reviews for achieving character education's success. However, there is no empirical study that links these four aspects.

Khan \& Law (2018) stated that character education in a country is influenced by developing cultural values. These values have a significant role in determining the success of the changes to determine. In Indonesia, character education is carried out by paying attention to national values (national character education) based on the nation's ideology, namely Pancasila. National character education is the understanding, appreciation, and practice of national moral values as a planned effort to make students know, care for, and internalize them in carrying out a cultural and national life in Indonesia (Cahyani \& Isah, 2017; Kamaruddin, 2012). However, low student morality in Indonesia is still occurring and is increasingly showing improvement (Fahmy et al., 2015).

\subsection{The problem of the study}

Previous studies have not solved fundamental problems to improve student morale (Was et al., 2006). These studies generally involved teachers and students, i.e., cognitive development and attitudes. Meanwhile, teachers' research is related to good character development, social learning, and character education knowledge (Howard et al., 2004; Kamaruddin, 2012). Chowdhury (2016) stated that students' moral problems could not be solved in a short time. Meanwhile, the implementation of character education needs to pay attention to psychological development, social learning, and cognitive development (Lickona, 2007). Thus, there needs to be a more in-depth study to solve student morality 
through character education. Khoury (2017) stated that the most effective study to solve this problem involves primary school teachers as educators who "transfer character" at the early levels of formal school.

The descriptions above show that there are still many student morality problems that must be resolved by reviewing primary school teachers' perspectives. Besides, studies that examine the relationship and influence of perceptions of policy dissemination, communication, and motivation on character knowledge from primary school teachers as actors of implementing character education policies, especially in terms of national character education, have never been carried out. In contrast, empirical research that investigates the comparison and relationship of knowledge of the national character of primary school teachers with their cognitive and non-cognitive abilities needs to be done to analyze the factors that lead to the success of the goals of national character education itself (Yufiarti et al., 2018). In the context of this study, the cognitive abilities of primary school teachers that are considered are the knowledge of national characters. Meanwhile, non-cognitive abilities considered are perceptions of policy dissemination, communication, and primary school teachers' motivation. Thus, a study is needed to analyze the relationship and influence of perceptions of policy dissemination, communication, and motivation on national character knowledge from primary school teachers' perspective as the main actors in policy implementation.

The questions in this study are as follows.

- Does the perception of the policy dissemination affect the national character knowledge of primary school teachers?

- Does the communication affect the national character knowledge of primary school teachers?

- Does the motivation affect the knowledge of the national character of primary school teachers?

- Does the perception of policy dissemination affect primary school teacher communication?

- Does the perception of policy dissemination affect the motivation of primary school teachers?

- Does the communication affect the motivation of primary school teachers?

\section{Literature Review}

\subsection{Character and Character Education}

Character education is a conscious effort by the government to build national morality through education. From an educator's point of view, teachers are assigned to prepare and print student character by acting and making assessments according to curriculum objectives (Pane \& Patriana, 2016). The values in character education are values that develop, apply, and are recognized, believed, and agreed to be implemented by the state or its citizens (Ghufron, 2010).

The three main approaches in carrying out character education are (1) the cognitive development approach (often called moral education), which gives advantages to "knowing what is good"; (2) the caring approach emphasizes "wanting what is good,"; (3) traditional character education, which sees "doing good" as fundament (Cheung \& Lee, 2010). Therefore, character education can help develop students' ethics, morals, and responsibility while providing affection for students by showing and teaching good character (Kamaruddin, 2012).

\subsection{Character and National Character Knowledge}

The character comes from Greek, which means to mark and focus on applying the values of kindness in real actions or everyday behavior (Wynne \& Ryan, 1993). Meanwhile, Hill (1990) stated that good character is an inner motivation to do what is right according to the highest behavior standards in every situation. Character determines one's thoughts and the actions a person takes. Therefore, people who behave dishonestly, cheatingly, cruelly, and greedily are said to have bad/evil characters. On the 
other hand, those who have good behavior are honest and helpful are said to be people who have good character.

National Character Knowledge is the understanding, appreciation, and practice of a person's values towards character education following its ideology. (Cahyani \& Isah, 2017; Tannir \& Al-Hroub, 2013). Pancasila influences Indonesia as a country that carries character education as the nation's ideology. This character education is known as nationality character education. The values of national character knowledge consist of spirituality, love for the country, awareness of the nation and State, Pancasila, and the ability to defend it (Terhune, 1970). Thus, knowledge of the national character developed in schools in Indonesia must also be based on universal values. This is an intentional and proactive effort from the school to fill students' basic mindset, namely ethical values such as respect for themselves and others, responsibility, integrity, and discipline (Utami, 2012).

\subsection{Teacher's Non-Cognitive Abilities}

Teachers' non-cognitive abilities are understood as teachers' psychological potential that emphasizes aspects of knowledge (Klassen et al., 2018). The focus of non-cognitive abilities in this study is the perception of policy dissemination, communication, and primary school teachers' motivation that perception can be regarded as interpretation of things and from a thing (Amir et al., 2020; Fahyuni et al., 2020). According to Horton \& Hunt (1999), the perception of policy dissemination is, in principle, "a means for a policy to achieve its goals." A policy program must be socialized so that it has the desired impact or purpose. Outreach is seen as a process of interaction between a set of goals and actions capable of achieving policy objectives where the actors, organizations, procedures, and techniques are used together (Chimhowu et al., 2019). Therefore, the perception of policy dissemination can be interpreted as a teacher's perception of the principal's efforts to deliver, direct, and implement character education policies.

Communication is a forum for conveying policies to others optimally, which can only occur if someone delivers a message to others for a specific purpose. There is feedback in communication elements, namely information that returns from communication (teacher) to the communicator in response to the communicator's message (Kearney et al., 1985). Meanwhile, motivation is a person's mental and mental condition in various desires, hopes, encouragement, and needs to reduce the perceived gap (Chai et al., 2016). Motivation can also be defined as the enthusiasm or encouragement for someone to carry out a series of activities by working hard and smartly to achieve specific goals. Motivation is the teacher's enthusiasm or encouragement for students to carry out a series of actions by working hard and smartly to achieve learning goals (Anwer, 2019; Barrett, 2007).

\section{Research Methods}

\subsection{Research Methods and Participants}

This study applied a survey method with structural equation models to determine the independent variables' effect (policy dissemination, communication, and motivation) on the dependent variable (national character knowledge). Policy dissemination, teacher communication, teacher motivation, and national character knowledge are represented by $\mathrm{X}_{1}, \mathrm{X}_{2}, \mathrm{X}_{3}$, and $\mathrm{Y}$, respectively. Structural equation modeling includes six key steps: data collection, model specification, identification, estimation, evaluation, and modification. The model of the relationship between the independent and dependent variables is depicted through the problem constellation in Figure 1. 
$\mathrm{X}_{1}$ : Policy dissemination

$\mathrm{X}_{2}$ : Communication

$\mathrm{X}_{3}$ : Motivation

Y: Knowledge of National Character

$\mathrm{P}_{\mathrm{Y}_{1}}$ : Effect of $\mathrm{X}_{1}$ on $\mathrm{Y}$

$\mathrm{P}_{\mathrm{Y}_{2}}$ : Effect of $\mathrm{X}_{2}$ on $\mathrm{Y}$

$\mathrm{P}_{\mathrm{Y}_{3}}$ : Effect of $\mathrm{X}_{3}$ on $\mathrm{Y}$

$\mathrm{P}_{\mathrm{X}_{1}}$ : The effect of $\mathrm{X}_{1}$ on $\mathrm{X}_{2}$

$\mathrm{P}_{\mathrm{X}_{2}}$ : The effect of $\mathrm{X}_{1}$ on $\mathrm{X}_{3}$

$\mathrm{P}_{\mathrm{X}_{3}}$ : The effect of $\mathrm{X}_{2}$ on $\mathrm{X}_{3}$

Figure 1: Problem Constellation

The study was conducted at a Primary School/Madrasah Ibtidaiyah in Pati, Central Java, Indonesia. Data collection was carried out for seven months from 2019 to 2020 using a purposive technique. Participants were 144 primary school teachers in Pati who were determined by specific criteria (Cresswell, 2012). The sampling criteria were primary school teachers who were certified class teachers and participated in the Indonesian government's Professional Teacher Training Practice program. The hypothesis in this study consists of six hypotheses, namely:

$\mathrm{H}_{1}$ = Policy dissemination directly affects the knowledge of primary school teachers' national character.

$\mathrm{H}_{2}=$ Communication has a direct positive influence on the knowledge of primary school teachers' national character.

$\mathrm{H}_{3}$ = motivation has a positive direct effect on the knowledge of primary school teachers' national character.

$\mathrm{H}_{4}$ = Policy dissemination has a positive direct effect on primary school teacher communication.

$\mathrm{H}_{5}=$ Policy dissemination has a positive direct effect on primary school teacher motivation.

H6 = Communication has a positive direct effect on primary school teacher motivation.

\subsection{Instruments}

The instruments used in this study were a questionnaire filled out by primary school teachers, consisting of a questionnaire of knowledge, perceptions of policy dissemination, communication, and teacher motivation in national character education. Each instrument had five alternative answer choices and scoring on a Likert scale from strongly agree (score 5), agree (score 4), doubt (score 3), disagree (score 2), and disagree (score 1).

Before being used, all instruments were tested on 30 primary school teachers in Pati City who had the same characteristics as the study participants to obtain the instrument's validity and reliability. The validity value was obtained using the Pearson product-moment correlation, while the reliability value was obtained using the Cronbach Alpha. 
Table 1: Research instrument validity and reliability result

\begin{tabular}{|l|c|c|c|}
\hline Instrument & $\mathbf{n}$ & Validity Score & Reliability Score \\
\hline National character knowledge questionnaire & 30 & 0.598 & 0.813 \\
\hline Policy dissemination questionnaire & 30 & 0.422 & 0.797 \\
\hline Communication questionnaire & 30 & 0.638 & 0.854 \\
\hline Motivation questionnaire & 30 & 0.599 & 0.706 \\
\hline
\end{tabular}

Table 1 shows that all instruments have a validity value $>\mathrm{r}$ table (0.3494) and a reliability value> 0.70 . Thus, it was concluded that the instruments used were valid and reliable.

\subsubsection{Knowledge Questionnaire}

The knowledge questionnaire aimed to determine the cognitive understanding of primary school teachers regarding national character. This questionnaire consists of 30 questions, which includes five indicators and sub-indicators of national character knowledge as follows: (1) spirituality (religious, honest, social care); (2) love the country (love peace, care for the environment, and love the country); (3) awareness of the nation and state (spirit of nationhood and friendly/communicative); (4) Pancasila (tolerance and democracy); (5) the ability to defend the country (respect for achievement) (Terhune, 1970).

\subsubsection{Policy dissemination Questionnaire}

The policy dissemination perception questionnaire aimed to determine primary school teachers' perceptions regarding their school principals' efforts in delivering, directing, and implementing the national character education policy. This questionnaire consists of 12 statements covering three indicators of the success of policy dissemination as follows: (1) human resources (managers, teaching staff, and students); (2) learning resources (curriculum, and modules and references); (3) disposition of policy implementer (integrity) (Mead, 2007).

\subsubsection{Communication Questionnaire}

The communication questionnaire aimed to determine the teacher's efforts in communicating the results of the policy dissemination on the understanding of national character education to fellow teachers, the school environment, and the community. This questionnaire consists of twenty statement items covering five indicators of (1) credibility (achievement, scientific specifications, competency experience in the field being engaged in, popularity, and dedication to the profession in which they are engaged); (2) capability (detail, consistency, and combination of verbal and non-verbal communication); (3) clarity (clarity and accuracy of speech); (4) sympathy (intensity of smile, eye contact, friendly attitude, neat appearance, and cheerfulness); (5) enthusiasm (high spirits, agile movements, fit stamina, radiant face, and energetic appearance) (Ibrahim et al., 2019).

\subsubsection{Motivation Questioannaire}

The motivation questionnaire aimed to determine the teacher's efforts in improving the understanding of national character education after getting socialization and communication from the Pati District Education Office. This questionnaire consists of fifteen statements covering four indicators as follows: (1) attention (trying to excel); (2) confidence (completing tasks); (3) relevance (rational in achieving success); (4) confidence (accepting and carrying out responsibility), (5) satisfaction (receiving feedback on work taking into account risks) (Wasserman et al., 2016).

\subsection{Data analysis}

This data was analyzed using the Structural Equation Model (SEM) with descriptive statistics and inferential statistics. The data obtained were statistically descriptive, including mean, standard deviation, median, variance, minimum score, and maximum score. Meanwhile, the data obtained by 
inferential statistics include data normality, regression test, and linearity test, and goodness of fit statistics test. A standard score was also used to test the path coefficient's significance using the t-test and compare the t-value with the t-table (Creswell et al., 2015). The data obtained were processed using the Linear Structural Relations Program (LISREL) 8.70 for Windows, which is used to estimate structural coefficients and unknown parameters, test the model's accuracy with empirical data, and modify the model if necessary (Raykov \& Marcoulides, 2012).

\section{Research Results}

The data description presentation starts with variable Y (knowledge of a national character) as the final endogenous variable, variable $\mathrm{X}_{\mathbf{1}}$ (perception of policy dissemination) as the exogenous variable and variable $\mathrm{X}_{2}$ (communication) as the intermediate endogenous variable, and $\mathrm{X}_{3}$ (motivation) as the variable (intervening). The results of the descriptive statistics in Table 2.

Table 2: Descriptive statistics

\begin{tabular}{|l|c|c|c|c|c|c|}
\hline & Mean & Std & Median & Variance & Minimum & Maximum \\
\hline National character knowledge & 119.79 & 9.188 & 120 & 84.41 & 99 & 140 \\
\hline Policy dissemination & 50.82 & 4.723 & 51 & 22.30 & 42 & 60 \\
\hline Communication & 76.38 & 6.166 & 77 & 38.01 & 64 & 89 \\
\hline Motivation & 61.41 & 4.814 & 61 & 23.17 & 50 & 70 \\
\hline
\end{tabular}

Table 2 shows the descriptive statistical results of national characters' knowledge in terms of perceptions of policy dissemination, communication, and motivation of primary school teachers. In the knowledge of the teacher's national character, the mean test for all participants is 119.79 out of 140 . The mean results indicate that the knowledge of the national character of the teacher is classified as good. The perception of teaching character education policies' socialization has a mean test result, which is also classified as good with a value of 50.82 out of 60 . Meanwhile, teacher communication is quite good, as shown by the mean results, with a 76.38 out of 90 . Finally, teacher motivation in character education was classified as very good with a mean of 61.41 out of 70 . After the data were analyzed using descriptive statistics, the research data were analyzed using inferential statistics, namely the normality of the data and the linear regression values, before entering the SEM analysis model. The data normality test and linear regression results are shown in Tables 3 and 4, respectively.

Table 3: Normality Test Calculation Result

\begin{tabular}{|c|c|c|c|c|c|c|}
\hline \multicolumn{7}{|c|}{ Tests of Normality } \\
\hline & \multicolumn{3}{|c|}{ Kolmogorov-Smirnov $^{\mathrm{a}}$} & \multicolumn{3}{|c|}{ Shapiro-Wilk } \\
\hline & Statistic & $\mathrm{df}$ & Sig. & Statistic & $\mathrm{df}$ & Sig. \\
\hline Unstandardized Residual Y-X1 & .057 & 91 & $.200^{*}$ & .988 & 91 & .556 \\
\hline Unstandardized Residual Y-X2 & .060 & 91 & $.200^{*}$ & .978 & 91 & .133 \\
\hline Unstandardized Residual Y-X 3 & .073 & 91 & $.200^{*}$ & .986 & 91 & .428 \\
\hline Unstandardized Residual X2-X1 & .048 & 91 & $.200^{*}$ & .985 & 91 & .362 \\
\hline Unstandardized Residual X3-X1 & .059 & 91 & $.200^{*}$ & .987 & 91 & .510 \\
\hline Unstandardized Residual $\mathrm{X}_{3}-\mathrm{X}_{2}$ & .055 & 91 & $.200^{*}$ & .981 & 91 & .212 \\
\hline \multicolumn{7}{|c|}{ *. This is a lower bound of the true significance. } \\
\hline a. Lilliefors Significance Correctio & & & & & & \\
\hline
\end{tabular}

Table 3 shows that the distribution of data on the variables of national character knowledge, perceptions of teacher policy dissemination, teacher communication, and teacher motivation is normally distributed based on the calculation of the Kolmogorov-Smirnov and Shapiro-Wilk normality 
test. From these results, it is known that L-count $\leq$ L-table, so it can be concluded that the three variables are normally distributed.

Table 4: Significance and Linearity of Regression Test Result

\begin{tabular}{|c|c|c|c|c|c|c|}
\hline \multirow{3}{*}{ Reg } & \multirow{3}{*}{ Equation } & \multicolumn{2}{|c|}{ Regression Test } & \multicolumn{2}{|c|}{ Linearity Test } & \multirow{3}{*}{ Conclusion } \\
\hline & & \multirow{2}{*}{ F-Count } & $\mathbf{F}_{\text {-table }}$ & \multirow{2}{*}{ F-count } & \multirow{2}{*}{$\begin{array}{c}\text { F }_{\text {Table }} \\
\alpha=\mathbf{0 , 0 5}\end{array}$} & \\
\hline & & & $\alpha=0,05$ & & & \\
\hline $\mathrm{Y}$ on $\mathrm{X}_{1}$ & $\mathrm{Y}_{=79,033}+0,802 \mathrm{X}_{1}$ & 18,218 & $3,95^{*}$ & 1,360 & $1,77^{\mathrm{ns}}$ & Regression is sig./linear \\
\hline Y on $\mathrm{X}_{2}$ & $\widehat{\mathrm{Y}}_{=74,599+0,592 \mathrm{X}_{2}}$ & 16,657 & $3,95^{*}$ & 0,948 & $1,70^{\mathrm{ns}}$ & Regression is sig./linear \\
\hline $\mathrm{Y}$ on $\mathrm{X}_{3}$ & $\widehat{\mathrm{Y}}=68,548+0,834 \mathrm{X}_{3}$ & 21,041 & $3,95^{*}$ & 0,195 & $1,78^{\mathrm{ns}}$ & Regression is sig./linear \\
\hline $\mathrm{X}_{2}$ on $\mathrm{X}_{1}$ & $\widehat{X}_{2}=53,642+o, 447 X_{1}$ & 11,845 & $3,95^{*}$ & 1,509 & $1,77^{\text {ns }}$ & Regression is sig./linear \\
\hline $\mathrm{X}_{3}$ on $\mathrm{X}_{1}$ & $\tilde{X}_{3}=43,517+0,352 X_{1}$ & 12,046 & $3,95^{*}$ & 0,732 & $1,77^{\mathrm{ns}}$ & Regression is sig./linear \\
\hline $\mathrm{X}_{3}$ on $\mathrm{X}_{2}$ & $\bar{X}_{3}=42,726+0,245 X_{2}$ & 9,681 & $3,95^{*}$ & 1,211 & $1,70^{\text {ns }}$ & Regression is sig./linear \\
\hline
\end{tabular}

Explanation: * : Significant ns : Non significant (regression is linear)

Table 4 shows that the overall test results for the significance and linearity of the data. The significance result shows that it has a significant regression value or linear regression, while the linearity test shows that the Fcount is smaller than the F-Table (2267> 1.70) with $\alpha=0,05$ and p-value (0.269>0.05). Thus, it can be concluded that the distribution of the regression equation data $\mathrm{Y}, \mathrm{X}_{1}, \mathrm{X}_{2}$, and $\mathrm{X}_{3}$ are linearly distributed.

Before performing calculations to test the causality model using SEM analysis, the research model's constellation must meet the goodness of fit test or the empirical data fit test with the research model and then the data, which is followed by testing each path/research hypothesis. Model suitability testing is needed to determine whether the proposed hypothetical model is consistent with empirical data. The model fit test is done by comparing the theoretical correlation matrix with the empirical correlation matrix. The output of the calculation results with Lisrel on "Goodness-of-Fit Statistics" for the statistical model fit test is shown in Table 5 .

Table 5: Goodness of Fit Statistics Result

\begin{tabular}{|l|c|c|c|}
\hline The goodness of Fit Index & Cut-off value & Test Model Results & Category \\
\hline Chi-Square & & 0.0 & Average \\
\hline Significance Probability & $\geq 0.05$ & 0.5 & Good \\
\hline GFI & $\geq 0.90$ & 0.912 & Good \\
\hline AGFI & $\geq 0.90$ & 0.834 & Average \\
\hline TLI & $\geq 0.95$ & 0.899 & Average \\
\hline CFI & $\geq 0.95$ & 0.951 & Good \\
\hline RMSEA & $\leq 0.08$ & 0.055 & Good \\
\hline CMIN-DF & $\leq 2.00$ & 0.988 & Good \\
\hline
\end{tabular}

Model suitability was checked using five absolute fit indices. The five indices of absolute conformity are (a) the ratio ${ }^{2}$ to the degrees of independence $\left(\chi^{2} / d f\right)$; (b) Root Mean Square Error of Approximation (RMSEA); (c) Indeks Kecocokan Komparatif (CFI); (d) Goodness of Fit (GFI); and (d) Indeks Tucker-Lewis (TLI). Indeks goodness-of-fit is generally used to identify measurement models and structural fit models (Yeop et al., 2016).

Based on Hair et al. (2017), if the CFI and GFI values are lower than 0.95, the RMSEA value must be $<0.05$. A score below three of $\chi^{2} / \mathrm{df}$ reflects the acceptable value of conformity. The preliminary results of the measurement model indicate an acceptable fit of the model. For the structural model, $\chi^{2}$ Statistic value $=0.0 ; \chi^{2} / \mathrm{df}=1,52 ; \mathrm{GFI}=0.912 ; \mathrm{CFI}=0.951 ; \mathrm{RMSEA}=.055 ; \mathrm{TLI}=0.899$. The results show 
that all proposed measurement models can be relied on for testing structural equation models. Table 5 provides the test results and proves that the proposed model is suitable because all values are within the acceptable threshold recommended by Hair et al. (2017).

The path coefficient calculation is done by continuing the calculation of the correlation coefficient on each path based on the structural equation in the structural equation model. The SEM analysis results are shown in Table 6 and Figure 2.

Table 6: Hypothesis testing results with Structural Equation Model

\begin{tabular}{|c|c|c|c|c|c|}
\hline Hypothesis & Path & Path Coefficient & t-count & Hypothesis result & Directions \\
\hline $\mathrm{H}_{1}$ & $\mathrm{X}_{1} \rightarrow \mathrm{Y}$ & $\mathbf{0 . 4 1 2}$ & $\mathbf{2 , 4 0 4}$ & Significant & Positif $(+)$ \\
\hline $\mathrm{H}_{2}$ & $\mathrm{X}_{2} \rightarrow \mathrm{Y}$ & $\mathbf{0 , 2 2 7}$ & $\mathbf{2 , 3 3 8}$ & Significant & Posiive $(+)$ \\
\hline $\mathrm{H}_{3}$ & $\mathrm{X}_{3} \rightarrow \mathrm{Y}$ & $\mathbf{0 , 2 8 5}$ & $\mathbf{2 , 9 3 0}$ & Significant & Posiive $(+)$ \\
\hline $\mathrm{H}_{4}$ & $\mathrm{X}_{1} \rightarrow \mathrm{X}_{3}$ & $\mathbf{0 , 2 7 0}$ & $\mathbf{2 , 5 9 6}$ & Significant & Posiive $(+)$ \\
\hline $\mathrm{H}_{5}$ & $\mathrm{X}_{2} \rightarrow \mathrm{X}_{3}$ & $\mathbf{0 , 2 2 1}$ & $\mathbf{2 , 1 2 6}$ & Significant & Posiive $(+)$ \\
\hline $\mathrm{H}_{6}$ & $\mathrm{X}_{1} \rightarrow \mathrm{X}_{2}$ & $\mathbf{0 , 3 4 3}$ & $\mathbf{3 , 4 4 2}$ & Significant & Posiive $(+)$ \\
\hline
\end{tabular}

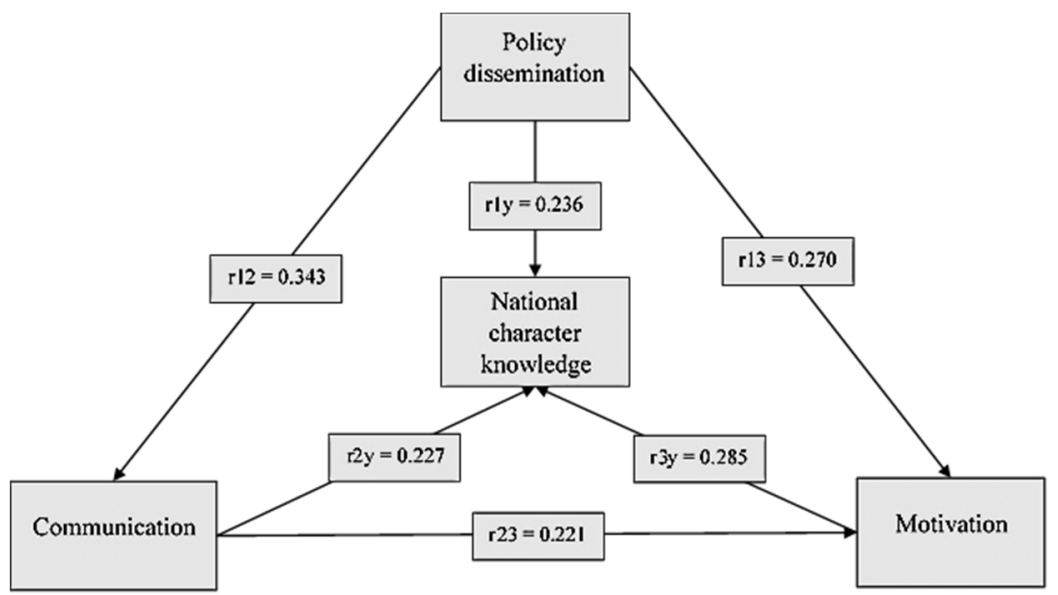

Figure 2: The flow and calculation results of the SEM path coefficient on the four variables

Tables 6 and 2 show the correlation and magnitude of policy dissemination, communication, and motivation by primary school teachers on their national character knowledge. The analysis results show that teacher communication on national character knowledge is not much different from the effect of teacher communication on teacher motivation. Besides, the main findings indicate that the teacher motivation variable has the greatest significant effect on the knowledge of primary school teachers' national character with a path correlation value of 0.285 . Meanwhile, on the other hand, the path correlation value of the knowledge of policy dissemination to the knowledge of national characters is 0.236 , and the path correlation value of teacher communication to the knowledge of the national character is 0.227 . Thus, the hypotheses $\mathrm{H}_{1}, \mathrm{H}_{2}$, and $\mathrm{H}_{3}$ are partially supported by this study's analysis.

Meanwhile, $\mathrm{H}_{4}, \mathrm{H}_{5}$, and $\mathrm{H}_{6}$ showed significant results very well. The highest path correlation value is found in the influence of the perception of policy dissemination on teacher communication with a value of 0.343 . Furthermore, the path correlation value between the socialization of character education policies on teacher motivation has an effective value of 0.270 . Finally, the path correlation value of the influence of teacher communication on teacher motivation is $\mathbf{0 . 2 2 1}$. Thus, these four variables have a positive and significant correlation. 


\section{Discussion}

This study provides a value for the influence of perceptions of policy dissemination, communication, and teacher motivation through a structural equation model that provides a new contribution that there is a significant continuity between these influencing variables on national character knowledge. This study's main findings indicate an influence between perceptions of policy dissemination, communication, and teacher motivation on national character knowledge.

This study's findings are supported by previous studies, such as Cahyani \& Isah (2017), which showed that the frequency of teachers' national characters' frequency increases accompanied by increased teacher motivation in understanding national character to students. Besides, teachers' perceptions of adequate policy dissemination can help teachers communicate nationality characters' knowledge to their students (Cheung \& Lee, 2010). Teacher communication is seen as the terminology of disseminating national values to convey and exemplify character education values (Alderson, 2001). Also, teacher communication and perceptions are influenced by the purpose of policy dissemination, which is for the target group or target group to know and understand the aims and objectives of policy implementation. So, the policies that have been made can be implemented according to the public policy formulation process (Wilson \& Epelle, 2018).

Other findings indicate that teacher communication has a positive direct effect on national character knowledge. Similar to these findings, Purnamasari, Ardia, \& Handoko (2018) and Wolf \& Moser (2011) found that a comprehensive teacher communication strategy by paying attention to awareness, attitude change, attitude change, and behavior changes can instill knowledge of national character in students. Besides showing a direct influence on teachers' cognitive abilities, namely the teacher's national character's knowledge, this study's results also show a direct positive influence between teachers' non-cognitive abilities. Perceptions of policy dissemination affect teacher communication and motivation. In addition, teacher communication affects teacher motivation, so that teachers with good non-cognitive abilities can provide good work competence. As an alternative in character education, developing one of the teacher's non-cognitive abilities can help develop other non-cognitive abilities (Heckman \& Rubinstein, 2001).

\section{Conclusion}

The cognitive abilities of teachers that are the focus of this study are knowledge of national characters. Meanwhile, teachers' non-cognitive abilities are in the form of policy dissemination, communication, and primary school teachers' motivation. These focuses are presented through a structural equation model. The results and discussion concluded that the perception of policy dissemination, communication, and motivation as non-cognitive abilities impacts knowledge of the nationality character of primary school teachers. Teacher motivation gives a significant positive path effect value on the knowledge of teacher nationality characters. In addition to the influence of non-cognitive abilities on teachers' cognitive abilities, there is a positive influence between teachers' non-cognitive abilities. Policy dissemination has a direct influence on teacher communication and motivation in character education. Teacher communication also has a direct effect on teacher motivation in national character education. This study recommends policy stakeholders, including school principals, to make nationality character education successful, including character education in general. Policy dissemination can be maximally and accurately implemented for primary school teachers. In the process, this policy's implementation must pay attention to the success factors that affect the knowledge of primary school teachers' national character, including perceptions of policy dissemination, communication, and motivation of primary school teachers. 


\section{References}

Alderson, K. (2001). Making Sense of State Socialization. Review of International Studies, 27(3), 415-433. https://www.jstor.org/stable/20097743

Amir, M. F., Fediyanto, N., Rudyanto, H. E., Afifah, D. S. N., \& Tortop, H. S. (2020). Elementary students' perceptions of 3Dmetric : A cross-sectional study. Heliyon, 6(6), 1-8. https://doi.org/10.1016/j.heliyon.2020.e04052

Anwer, F. (2019). Activity-Based Teaching, Student Motivation and Academic Achievement. Journal of Education and Educational Development, 6(1), 154-170.

Barrett, A. M. (2007). Beyond the polarization of pedagogy: models of classroom practice in Tanzanian primary schools. Comparative Education, 43(2), 273-294. https://doi.org/10.1080/03050060701362623

Berkowitz, M. W., \& Hoppe, M. A. (2009). Character education and gifted children. High Ability Studies, 2o(2), 131142. https://doi.org/10.108o/13598130903358493

Cahyani, C., \& Isah, I. (2017). The National Character Education Paradigm in the Indonesian language instructions. Proceedings of the Ninth International Conference on Applied Linguistics (CONAPLIN 9). https://doi.org/10.2991/conaplin-16.2017.61

Chai, C. S., Wong, L. H., \& King, R. B. (2016). Surveying and modeling students' motivation and learning strategies for mobile-assisted seamless Chinese language learning. Educational Technology and Society, 19(3), 170-180. https://doi.org/10.2307/jeductechsoci.19.3.170

Cheung, C. K., \& Lee, T. Y. (2010). Improving social competence through character education. Evaluation and Program Planning, 33(3), 255-263. https://doi.org/10.1016/j.evalprogplan.2009.08.006

Chimhowu, A. O., Hulme, D., \& Munro, L. T. (2019). The 'New' national development planning and global development goals: Processes and partnerships. World Development, 120, 76-89. https://doi.org/10.1016/j.worlddev.2019.03.013

Chowdhury, M. (2016). Emphasizing morals, values, ethics, and character education in science education and science teaching. The Malaysian Online Journal of Educational Science, 4(2), 1-16.

Cresswell, J. W. (2012). Planning, conducting, and evaluating quantitative and qualitative research. Educational Research, 10, 1-12. https://doi.org/https://doi. org/10.4135/9781483349435

Creswell, K. G., Chung, T., Wright, A. G. C., Clark, D. B., Black, J. J., \& Martin, C. S. (2015). Personality, negative affect coping, and drinking alone: A structural equation modeling approach to examine correlates of adolescent solitary drinking. Addiction, 110(5), 775-783. https://doi.org/10.1111/add.12881

Fahmy, R., Bachtiar, N., Rahim, R., \& Malik, M. (2015). Measuring Student Perceptions to Personal Characters Building in Education: An Indonesian Case in Implementing New Curriculum in High School. Procedia - Social and Behavioral Sciences, 211, 851-858. https://doi.org/10.1016/j.sbspro.2015.11.112

Fahyuni, E. F., Wasis, Bandono, A., \& Arifin, M. B. U. B. (2020). Integrating islamic values and science for millennial students' learning on using seamless mobile media. Jurnal Pendidikan IPA Indonesia, 9(2), 231-240. https://doi.org/10.15294/jpii.v9i2.23209

Ghufron, A. (2010). Integrasi nilai-nilai karakter bangsa pada kegiatan pembelajaran. Jurnal Cakrawala Pendidikan, $1(3), 13-24$.

Gou-Zeh, Y. (1979). Moral Education in Korea. Journal of Moral Education, 8(2), 75-80. https://doi.org/10.1080/0305724790080201

Hair, J. F., Babin, B. J., \& Krey, N. (2017). Covariance-Based Structural Equation Modeling in the Journal of Advertising: Review and Recommendations. Journal of Advertising, 46(1), 163-177. https://doi.org/10.108o/o0913367.2017.1281777

Heckman, J. J., \& Rubinstein, Y. (2001). The Importance of Noncognitive Skills: Lessons from the GED Testing Program. American Economic Review, 91(2), 145-149. https://doi.org/10.1257/aer.91.2.145

Hill, P. T. (1990). High schools with character. RAND Corporation.

Horton, P. B., \& Hunt, C. L. (1999). Sosiologi Jilid 1. Erlangga.

Howard, R. W., Berkowitz, M. W., \& Schaeffer, E. F. (2004). Politics of Character Education. Educational Policy, 18(1), 188-215. https://doi.org/10.1177/0895904803260031

Ibrahim, M. Y., Yusof, M. R., Yaakob, M. F. M., \& Othman, Z. (2019). Communication Skills: Top Priority of Teaching Competency. International Journal of Learning, Teaching and Educational Research, 18(8), 17-30. https://doi.org/10.26803/ijlter.18.8.2

Kamaruddin, S. A. (2012). Character Education and Students Social Behavior. Journal of Education and Learning, 6(4), 223-230.

Katilmiș, A., Ekși, H., \& ÖztÜrk, C. (2011). Efficiency of Social Studies Integrated Character Education Program. Educational Sciences: Theory \& Practice, 11(2), 854-859. 
Kearney, P., Plax, T. G., Richmond, V. P., \& McCroskey, J. C. (1985). Power in the classroom III: Teacher communication techniques and messages. Communication Education, 34(1), $19-28$. https://doi.org/10.108o/o3634528509378579

Khan, M. A., \& Law, L. S. (2018). The Role of National Cultures in Shaping the Corporate Management Cultures: A Three-Country Theoretical Analysis. In Organizational Culture. IntechOpen. https://doi.org/10.5772/intechopen.78051

Khoury, R. (2017). Character Education as a Bridge from Elementary to Middle School: A Case Study of Effective Practices and Processes Ruba Khoury. International Journal of Teacher Leadership, 8(2), 49-67.

Klassen, R. M., Durksen, T. L., Al Hashmi, W., Kim, L. E., Longden, K., Metsäpelto, R.-L., Poikkeus, A.-M., \& Györi, J. G. (2018). National context and teacher characteristics: Exploring the critical non-cognitive attributes of novice teachers in four countries. Teaching and Teacher Education, 72, 64-74. https://doi.org/10.1016/j.tate.2018.03.001

Lickona, T. (2007). Eleven Principles of Effective Character Education. Journal of Moral Education, 36(1), 79-92.

Mead, G. H. (2007). The social foundations and functions of thought and communication. In Theorizing communication: Readings across traditions (pp. 371-376).

Nyabul, P. (2009). Moral Education and the Condition of Africa. Thought and Practice: A Journal of the Philosophical Association of Kenya, 1(1). https://doi.org/10.4314/tp.vii1.46305

Pane, M. M., \& Patriana, R. (2016). The Significance of Environmental Contents in Character Education for Quality of Life. Procedia - Social and Behavioral Sciences, 222, 244-252. https://doi.org/10.1016/j.sbspro.2016.05.153

Purnamasari, O., Ardia, V., \& Handoko, D. (2018). Persuasive Communication Pattern of Public Service Announcement, A Highlight of Cancer Education by Indonesia Government in Television. Malaysian Journal of Social Sciences and Humanities, 3(1), 52-61.

Raykov, T., \& Marcoulides, G. A. (2012). A first course in structural equation modeling. Routledge taylor \& Francis Group.

Rokhman, F., Syaifudin, A., \& Yuliati. (2014). Character Education for Golden Generation 2045 (National Character Building for Indonesian Golden Years). Procedia - Social and Behavioral Sciences, 141, $1161-1165$. https://doi.org/https://doi.org/10.1016/j.sbspro.2014.05.197

Tannir, A., \& Al-Hroub, A. (2013). Effects of Character Education on the Self-Esteem of Intellectually Able and Less Able Elementary Students in Kuwait. International Journal of Special Education, 28(2), 47-59.

Terhune, K. W. (1970). From National Character to National Behavior: A Reformulation. The Journal of Conflict Resolution, $14(2), 203-263$.

Utami, I. L. P. (2012). Character Education through Peer Assessment. Jurnal Pendidikan Karakter, 3, 1-16.

Was, C. A., Woltz, D. J., \& Drew, C. (2006). Evaluating character education programs and missing the target: A critique of existing research. Educational Research Review, 1(2), 148-156. https://doi.org/10.1016/j.edurev.2006.o8.oo1

Wasserman, E., Ben-eli, S., Yehoshua, O., \& Gal, R. (2016). Relationship between the Principal's Leadership Style and Teacher Motivation. International Journal of Learning, Teaching and Educational Research, 15(10), $180-192$.

Wilson, G., \& Epelle, A. (2018). Public policy formulation and implementation in contemporary Nigeria. International Journal of Research in Social Sciences, 8(6), 175-185. https://doi.org/10.13140/rg.2.2.13256.21763

Wolf, J., \& Moser, S. C. (2011). Individual understandings, perceptions, and engagement with climate change: insights from in-depth studies across the world. Wiley Interdisciplinary Reviews: Climate Change, 2(4), 547569. https://doi.org/10.1002/wcc.120

Wynne, E., \& Ryan, K. (1993). Reclaiming our schools: A handbook on teaching character, academics, and discipline. Simon \& Schuster Children's Publishing.

Yemini, M., Tibbitts, F., \& Goren, H. (2019). Trends and caveats: Review of literature on global citizenship education in teacher training. Teaching and Teacher Education, 77, 77-89. https://doi.org/10.1016/j.tate.2018.09.014

Yeop, M. A., Wong, K.-T., \& Goh, P. S. C. (2016). Blended learning: pedagogy, learning styles, and assessment activities in the classroom. International Journal of ADVANCED AND APPLIED SCIENCES, 3(11), 36-39. https://doi.org/10.21833/ijaas.2016.11.007

Yufiarti, Y., Rihatno, T., Nuraini, S., \& Sholikah, M. (2018). Character Building Methods Elementary School Teacher in Jakarta Region. Proceedings of the Annual Civic Education Conference (ACEC 2018). https://doi.org/10.2991/acec-18.2018.52 